\title{
The Development of Cognitive Behavior Therapy Guidebook to Improve Self-efficacy of People with HIV/AIDS
}

\author{
Najlatun Naqiyah, Bambang Dibyo Wiyono, Citra Fitri Kholidya \\ Universitas Negeri Surabaya \\ Surabaya, Indonesia \\ najlatunnaqiyah@unesa.ac.id
}

\begin{abstract}
The purpose of this research is to produce Cognitive Behavior Therapy (CBT) guidebook for people with HIV/AIDS (PWHA) that fulfill the criteria of acceptability, i.e. utility, accuracy, and feasibility aspects. This research uses Borg \& Gall development model. The data collection instrument used in this development is an acceptability assessment questionnaire. The validation results of the content experts show that the Cognitive Behavior Therapy (CBT) guidebook for people with HIV/AIDS (PWHA) is considered worthy of use.
\end{abstract}

Keywords - cognitive behavior therapy, guidebook, self-efficacy

\section{INTRODUCTION}

Indonesia is one of Asian countries with a high HIV/AIDS epidemic. Based on data from Indonesia Ministry of Health, cumulatively from April 1, 1987 to December 31, 2016, there were 232,323 cases of HIV, 86,725 cases of AIDS with the number of deaths reached 7,491 cases. The prevalence of national AIDS cases is 36.52 per 100,000 populations. East Java province is cumulatively the province with the largest number of HIV/AIDS cases. Furthermore, there are 40 million people infected with HIV worldwide [1].

Probolinggo regency is one of the areas in East Java province with a very worrying spread of HIV/AIDS. On average, the findings of 20 people with HIV/ AIDS (PWHA) appear almost every month [2]. The findings of HIV AIDS cases in February 2014 were 665 cases, increasing to 845 cases in November and reaching 900 cases in December. By 2015, 950 cases are developing. Most cases occur in Paiton, Krucil, Besuk and Dringu sub-districts. People with HIV/AIDS (PWHA) are able to live in full lifespan after getting infected. However, rates of anxiety disorders among this population are elevated compared to national samples. More importantly, these anxiety symptoms and disorders have a negative effect on medication adherence, quality of life and other psychological disorders, such as depression [3].

Research related to the handling of HIV/AIDS cases in Indonesia is a lot. According to the study by [4] during 20102013, WHO through Global Program on AIDS has several obstacles in handling HIV/AIDS cases in Indonesia including: (1) psychological and cultural problem; (2) area; (3) the purchasing power of treatment; and (4) deviant lifestyles. Furthermore, [5] shows that peer support has a significant role in the quality of life of PWHA, but unfortunately has not been integrated as a referral system for handling people living with HIV in all districts. Then, the program of service by [6] shows the importance of the basic character for the health personnel of PWHA. Furthermore, the cognitive therapy of religious behavior has an effect on decreasing anxiety to death of PWHA [7].

According to [8] counseling for PWHA is by helping clients to conduct informed consent for approval of HIV / CD4 or Viral-load testing. Pre- and post-test counseling services are client behavioral assessment of HIV/AIDS virus, client health history, confidentiality of issues and stigma of HIV/AIDS patients, reaching specific groups at risk, and changes in client behavior. This study aims to produce Cognitive Behavior Therapy (CBT) guidebook to improve the sense of success of people living with HIV/AIDS who meet the criteria of acceptability, namely utility, accuracy, and feasibility aspects. This research uses [9] development model which is adapted into five stages. The data collection instrument used in this development is a developed acceptability assessment questionnaire [10]. The validation results of the content/material show that the research product is considered feasible to use.

\section{METHOD}

This research uses Borg \& Gall development model. According to [9] this model is called research and development consisting of 10 development steps: (1) research and information gathering; (2) planning; (3) developed product preliminary form; (4) preliminary field tests; (5) major product revisions; (6) main field tests; (7) revision of operational product; (8) operational field tests; (9) revision of the final product; and (10) dissemination and distribution.

The Borg \& Gall development model was chosen because it gives developers access to every step without eliminating the meaning of the content and in accordance with the development goals. The development model is adapted into five stages due to consideration of time and cost of research. 


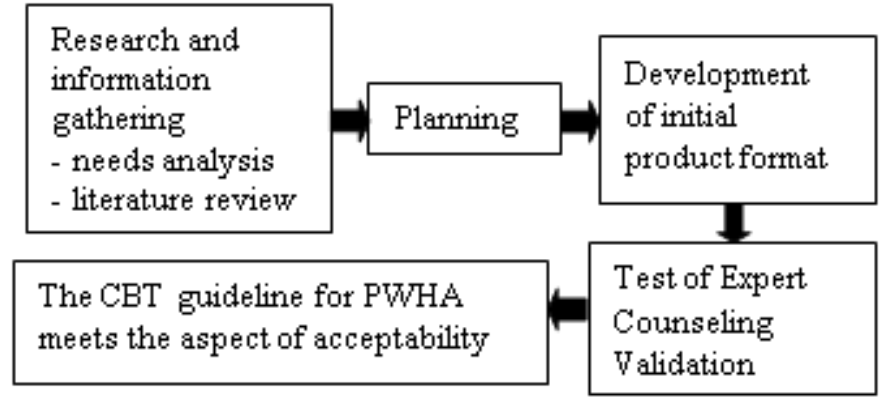

Fig. 1 Development Procedures adapted from [9]

The data collection instrument used in this development is an acceptability assessment questionnaire covering aspects of utility, accuracy and feasibility. This assessment questionnaire was developed from the book Standards for Evaluation of Educational Programs, Projects, and Materials [10]. The indicators of acceptability criteria guide are as follows:

a. The aspect of utility referring to the benefits of Cognitive Behavior Therapy (CBT) guidebook to improve the sense of self-efficacy of PWHA.

b. The aspect of accuracy referring to how much Cognitive Behavior Therapy (CBT) guidebook can enhance the selfefficacy of PWHA.

c. The aspect of feasibility referring to the practicality and effectiveness of the Cognitive Behavior Therapy (CBT) guidebook to improve the sense of self-efficacy of PWHA.

The developed questionnaire has 1-4 gradations. Each has the following meaning:

$1=$ unclear/inaccurate/inappropriate

2 = less obvious/less precise/less appropriate

3 = clear/proper/appropriate

4 = very clear/very precise/ very appropriate

If the assessed aspect was scored 3 or 4 then it was considered accurate and did not need to be revised, but if the assessed aspect was scored 1 or 2 then it was considered inaccurate and needed revisions. Developers follow up with interviews to assessors to get clearer and more accurate feedback

Special qualitative data analysis is performed on the experts' suggestion and comments. Qualitative data are presented in a transparent way to consider revising and improving the guidebook. Descriptive statistical analysis is used to process the data obtained in the form of percentage analysis. The percentage technique is used to present the data that is the frequency of the response of the subject trial to the product that has been developed. The analytical technique used to process the data according to [11] are:

$\mathrm{P}=$ total score of answers/ $\mathrm{n} \times$ highest weight $\mathrm{x} 100 \%$
Next, to calculate the percentage of all subjects the formula percentage was used. This percentage technique is used to present data which is the frequency of the response of the test subject to the product. The formula used is:

$$
P=\frac{\mathrm{F}}{\mathrm{N}}
$$

Notes: $\mathrm{P}=$ Percentage

$$
\begin{aligned}
& \mathrm{F}=\text { Total percent of subjects } \\
& \mathrm{N}=\text { Total number of test subjects }
\end{aligned}
$$

Decision making of product qualification level used qualification with criterion of interpretation as follows:

TABLE I INTERPRETATION CRITERIA

\begin{tabular}{cccc}
\hline No. & Range & Criteria & Alternative Decisions \\
\hline 1 & $81 \%-100 \%$ & Very good & Used \\
2 & $61 \%-80 \%$ & Good & Used and reviewed \\
3 & $41 \%-60 \%$ & Enough & Reviewed and revised \\
4 & $21 \%-40 \%$ & Less & Revised \\
5 & $0 \%-20 \%$ & Very less & Cannot be used \\
\hline Source $[12]$ & &
\end{tabular}

\section{RESUlTS AND DisCUSSION}

Expert content validation aims to get the material feasibility in the Guidance and Counseling book for PWHA. Expert content in this development is an expert lecturer in the field of Counseling Theory that is Dr. Budi Purwoko, M.Pd. (Expert 1) and Dra. Titin Indah Pratiwi, M.Pd. (Expert 2). Data obtained from the content expert in the Guidance and Counseling book for PWHA is in the form of quantitative and qualitative data. The quantitative data is in the form of the results of assessment and the qualitative data is in the form of advice to the product of development.

Assessment of expert content (expert 1) in the field of counseling theory on each indicator indicates that all indicators get score 3 and 4, thus, considered accurate and do not need to be revised. There are suggestions provided by expert content counseling theory about aspect number 1 regarding the title writing which needed revisions. Assessment of the expert content of the theory of counseling to the product as a whole shows total score 43 . The total percentage of the entire subject can be calculated by the formula:

$$
\mathrm{P}=43 /(13 \times 4) \times 100 \%
$$$$
\mathrm{P}=82.69 \%
$$

After the result of the total percentage of the whole subject $(\mathrm{F})$ is obtained then percentage $(\mathrm{P})$ is calculated using the formula:

$$
\begin{aligned}
& \mathrm{P}=\mathrm{F} / \mathrm{N} \\
& \mathrm{P}=(82.69 \%) / 1 \\
& \mathrm{P}=82.69 \%
\end{aligned}
$$



used.

Thus, with $\mathrm{P}=82.69 \%$, means "excellent" and can be

Expert assessment of the content of the theory of counseling (expert 2) on each indicator indicates that all indicators get score scores 3 and 4 so they are considered accurate and do not need revisions. However, the suggestions provided by the content counseling expert on aspect number 1 regarding the title writing is it needed revisions.

Expert judgment on the content of the theory of counseling to the product as a whole shows total score 46. The total percentage of the entire subject can be calculated by the formula:

\section{$\mathrm{P}=46 /(13 \times 4) \times 100 \%$ \\ $\mathrm{P}=88.46 \%$}

After the result of the total percentage of the whole subject (F) is obtained then percentage $(\mathrm{P})$ is calculated using the formula:

$$
\mathrm{P}=\mathrm{F} / \mathrm{N}
$$

$$
\mathrm{P}=(88.46 \%) / 1
$$

\section{$\mathrm{P}=88.46 \%$}

Thus, with $\mathrm{P}=88.46 \%$, it means "very good" and can be used.

Guidance and Counseling book for PWHA is a product that has been developed based on the analysis of the needs of people living with HIV. The book was developed from Borg \& Gall model adapted into five stages. However, with consideration of short research time then the development stage was done until the third stage. Product development begins with needs analysis, initial product design, guide production, expert test and revision. Expert testing process involves content / material specialists in the field of Counseling Theory.

This book has gone through the expert test phase and has been through revision. From the research process, the developers come to a conclusion that the product is worthy of use. There is only one component that needs to be revised that is writing the title of the book.

People with HIV/AIDS (PWHA) are mostly unable to accept the fact that they have been infected with the HIV virus. This book is structured to help people with HIV/AIDS (PWHA) accept themselves and adhere to the treatment they live. There are three important things in the book, i.e. if you have a sense of faith in God Almighty, a sense of confidence to be able to undergo regular treatment and discipline and the fulfillment of healthy and balanced nutrition. This is supported by the steps of CBT for HIV/AIDS patients in six stages [3], namely (1) expressing anxiety experienced by HIV/AIDS patients, (2) discussing CBT strategies to eliminate the impact of negative thoughts and feelings in life, (3) trying to change the old understanding with the new one and open new worldviews (4) sending an email about the patient's progress (5) rebuilding relationships with friends who have been avoided and (6) making an overview of the changes experienced in 2 weeks by living with the environment.
Counselors are in charge of implementing adherence support counseling and convey the basic workings of antiretroviral drugs, the occurrence of therapeutic failures and the avoidance of adherence, and the easy way of accessing these ARVs.

In addition, according to [13] there are many factors that contribute to therapeutic compliance including self efficacy, social support and depression levels. The involvement of self efficacy can be seen from perseverance, high motivation, thought, cognition and affection to improve the quality of life in the recent circumstances. Levels of depression and social support affect adherence in psychological states. Social stigma encourages people with HIV/AIDS to feel depressed. Likewise, the health of people with HIV will decrease if accompanied by the habit of drinking. [14] describes drug with hectare, which can further damage the health. The health of HIV / AIDS patients will improve if living with religious and spiritual thoughts, a sense of success for disciplined therapy and treatment as well as exercise and consuming healthy and nutritious food.

\section{CONLUSION}

The conclusions of this research are: (a) people with HIV/AIDS (PWHA) need media (books) to improve selfefficacy; (b) the book are developed based on the analysis of the needs of PWHA; (c) the development of Cognitive Behavior Therapy (CBT) books to enhance the sense of selfefficacy of PWHA is through validation of content/material experts and assessed as worthy of use. Based on the conclusions, some relevant research suggestions are: (a) the use of Cognitive Behavior Therapy (CBT) books to increase the sense of success (self-efficacy) of people with HIV/AIDS needs adequate explanation; (B) the use of Cognitive Behavior Therapy (CBT) books to enhance the self-efficacy of people living with HIV/AIDS requires periodic control and evaluation.

\section{References}

[1] R. Abadie, M. Welch-Lazoritz, B. Khan, and K. Dombrowski, "Social determinants of HIV/HCV coinfection: A case study from people who inject drugs in rural Puerto Rico," Addictive behaviors reports, vol. 5, pp. 29-32, 2017.

[2] W. Cicilia and H. Iis, "Factors That Influences of People Living With HIV/Aids (PLWHA) in VCT Division of General Hospital Waluyo Jati Kraksaan District Probolinggo," 2017.

[3] C. P. Brandt, D. J. Paulus, M. Garza, C. Lemaire, P. J. Norton, and M. J. Zvolensky, "A Novel Integrated Cognitive-Behavioral Therapy for Anxiety and Medication Adherence Among Persons Living With HIV/AIDS," Cognitive and Behavioral Practice, 2017.

[4] M. Putri and F. Rani, "Peran World Health Organization (WHO) dalam Upaya Penanganan HIV/Aids di Indonesia Tahun 2010-2013," Jurnal 
Online Mahasiswa (JOM) Bidang Ilmu Sosial dan Ilmu Politik, vol. 3, pp. 1-13, 2016.

[5] S. Handayani, "Peran Dukungan Sebaya terhadap Mutu Hidup PWHA di Indonesia Tahun 2011," UHAMKA, Jakarta, 2011.

[6] A. Alifatin, "Membangun Kharakter Kelompok Marginal (PWHA/ADHA) dengan Pendampingan Kesehatan," Jurnal Dedikasi, vol. 12, 2015.

[7] A. L. Paukert, L. Phillips, J. A. Cully, S. M. Loboprabhu, J. W. Lomax, and M. A. Stanley, "Integration of religion into cognitive-behavioral therapy for geriatric anxiety and depression," Journal of Psychiatric Practice ${ }^{\circledR}$, vol. 15, pp. 103-112, 2009.

[8] J. Mermin, J. P. Ekwaru, W. Were, R. Degerman, R. Bunnell, F. Kaharuza, et al., "Utility of routine viral load, CD4 cell count, and clinical monitoring among adults with HIV receiving antiretroviral therapy in Uganda: randomised trial," Bmj, vol. 343, p. d6792, 2011.
[9] M. D. Gall, W. R. Borg, and J. P. Gall, Educational research: An introduction: Longman Publishing, 1996.

[10] D. L. Stufflebeam, Standards for Evaluations of Educational Programs, Projects, and Materials: ERIC, 1981.

[11] M. P. K. Sugiyono, "kualitatif dan R\&D," Bandung: Alfabeta, vol. 124, 2008.

[12] R. MBA, "Dasar-dasar Statistika," ed: Bandung: Alfabeta, 2006.

[13] F. F. Widjaja, C. G. Puspita, F. Daud, I. Yudhistrie, M. R. Tiara, C. S. Suwita, et al., "Highly active antiretroviral therapy adherence and its determinants in selected regions in Indonesia," Medical Journal of Indonesia, vol. 20, p. 50, 2011.

[14] J. C. Elliott, D. S. Hasin, and D. C. Des Jarlais, "Perceived health and alcohol use in individuals with HIV and Hepatitis C who use drugs," Addictive behaviors, vol. 72, pp. 21-26, 2017. 